\title{
Periodontal Cases-Role of Nutrition \& Systemic Homeopathy
}

\author{
M Michalakis*, Aphrodite Chatzimanuil, Papadaki Helen and Michalaki Dernikou Fotini \\ Hellenic Classical Homeopathic Dental Association, Greece
}

Submission: October 26, 2017; Published: November 14, 2017

*Corresponding author: Michalakis Michail, DDS, MSc President of HCHDA, Greece, Email: mimichail@yahoo.co.uk

\section{Case Report}

Periodontal disease, a major dental disorder of the twentyfirst century, was also known in antiquity. Evidence of chronic periodontal disease has been described in a 3 million year old hominid; acute gingivitis/periodontitis was recorded in the army of the Greek General Xenophon in 400 BC. Cause of periodontal disease today in clinical practice is considered to be due to bacterial irritation brought about by the accumulation of plaque at the dentogingival junction [1]. Additionally, local and systemic factors are known to influence the progress of the disease $[2,3]$.

The Aim of this study is to investigate the role of nutrition into conservative Dentistry under classical homeopathy principles treatment both in Periodontal cases \& healthy individuals. Severe periodontal (gum) disease, which may result in tooth loss, is found in $15-20 \%$ of middle-aged (35-44 years) adults. Risk factors for oral diseases include an unhealthy diet, tobacco use, harmful alcohol use and poor oral hygiene, and social determinants [4]. Smoking and types 1 and 2 diabetes are well-established risk factors for periodontal disease.

Risk factor is one that has been associated with increased rate of a subsequently occurring disease but do not necessarily cause the disease.

Vegetarian and vegan diets contain low amounts of protein and calcium. For this reason they are supposed to cause low bone mineral density (BMD) and osteoporosis (Vegan). Nutritional acid load is negatively correlated with bone mineral density (BMD) and positively with fracture risk. Low acid load is correlated with lower bone resorption and higher BMD, it is linked to high intake of potassium-rich nutrients, such as fruits and vegetables [5] (Figure 1).

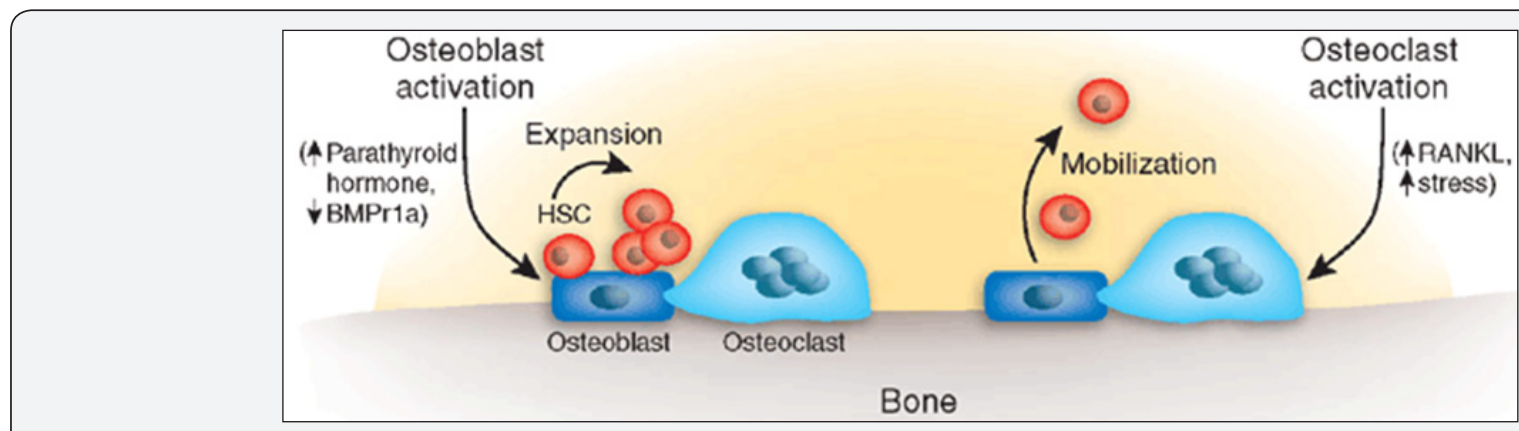

Figure 1

Homeopathy evaluates the mental, emotional and physical together with inheritance factor. The symptoms are not the disease itself, but uprising values that are explained as outcomes of the internal constitutional disturbance of the system. Each case was individually screened for Nutritional, Mechanical and Systemic deviations with potential to accelerate/cause bone absorption.

Patients were briefed upon the impact of their expose to factors in bone homeostasis, thus achieving a more positive attitude towards treatment, assisted with homeopathy.

\section{Recent Data of Cure and Disease in PD}

In recent years, it has become apparent that the pathogenesis of periodontal diseases is far more complex than the presence of virulent microorganisms. In fact, it is now widely accepted that susceptibility to periodontitis varies greatly between individuals who harbor the same, pathogenic microflora [6].

\section{Discussion}

Nutrition is a potentially modifiable risk factor that could drive or abrogate the underlying oxidative stress in periodontitis 
[7]. There have been suggestions in literature for nutritional supplements in advance to dental treatment for cases with gingivitis and P.D. Such as Vit-A,C,E,D, folic-acid, Coenzyme Q10, Zinc, Mg, Selenium [8,9]. Clinical observations together with recent scientific studies, placed together in each case encourage food supplements in such cases. Se status is positively associated with BMD in healthy aging men, independent of thyroid function [10]. Even thought research in this area is still in its infancy. It is likely that Se at least at high doses, can prevent bone resorption through the inactivation of osteoclasts [11]. Consistent with this observation, a recent study demonstrated that Se status was inversely related to bone turnover and positively correlated with BMD in healthy euthyroid postmenopausal women independent of thyroid status $[10,11]$ as well it Is positively associated with BMD Bone Mineral Density in Healthy Aging European Men [10]. Selenium and vitamin E act synergistically as antioxidants.

\section{Summary}

P.D is of multifactorial cause with delayed response to the harmful stimuli. The clinical outcome of a persons exposure to variable harmful factors (modifiable or non-modifiable) depends on both the intensity \& duration of such stimuli, however the overall health status \& immunity will mediate response which is translated from a clinical point of view, as recession of alveolar bone or not. "Successful" treatment will follow a similar manner, requires patient engagement, data related to each case has to be comprehensible to the patient as possible, diet adjustments simple to adapt daily. Future understanding of the biological mechanisms that control the immunopathogenesis of the remodeling and resorptive processes will clarify not only the local control of bone cell function but also the pathophysiology of accelerated bone loss, as seen in periodontal disease an other immune inflammatory diseases of bone such as osteoporosis and rheumatoid arthritis [12-16].

\section{Conclusion}

The identification of inflammatory periodontal disease, education in local and systemic risk factors and their management mutually with the words of Hippocrates forms the foundation of the treatment of this disease. "Let food be thy medicine and medicine be thy food."

\section{References}

1. RJ Forshaw (2009) Dental health and disease in ancient. Egypt British Dental Journal 206: 421-424.
2. Clarke NG, Carey SE, Srikandi W, Hirsh RS, Leppard PI (1986) Periodontal disease in ancient populations. Am J Phys Anthropol 71(2): 173-183.

3. Clarke NG (1990) Periodontal defects of pulpal origin: Evidence of early man. Am J Phys Anthropol 82(3): 371-376.

4. WHO Oral health Fact Key facts sheet Nº318 April 2012.

5. Beukhof CM, Medici M (2016) Selenium Status Is Positively Associated with Bone Mineral Density in Healthy Aging European Men. PLoS One 11(4): e0152748.

6. Collin B Lessell Textebook of Dental Homeopathy.

7. Stefan A Hienz, Sweta Paliwal, Saso Ivanovski (2015) Mechanisms of Bone Resorption in Periodontitis. J Immunol Res 2015: 615486.

8. Raindi D (2016) Nutrition and Periodontal Disease. Dent Update 43(1): 66-68, 71-72.

9. Huawei Zeng, Jay J Cao, Gerald F Combs (2013) Selenium in Bone Health: Roles in Antioxidant Protection and Cell Proliferation. Nutrients 5(1): 97-110.

10. Burckhardt P (2016) The role of low acid load in vegetarian diet on bone health: a narrative review. Swiss Med Wkly 146: w14277

11. Van Dyke TE, Sheilesh D (2005) Risk Factors for Periodontitis. J Int Acad Periodontol 7(1): 3-7.

12. Hamasaki T, Kitamura M, Kawashita Y, Ando Y, Saito T (2016) Periodontal disease and percentage of calories from fat using national data. J Periodontal Res 52(1): 114-121.

13. Wang J, Lv J, Wang W, Jiang X (2016) Alcohol consumption and risk of periodontitis: a meta-analysis. J Clin Periodontol 43(7): 572-583.

14. Biria M, Eslami G, Taghipour E, Akbarzadeh BA (2014) Effects of Three Mastic Gums on the Number of Mutans Streptococci, Lactobacilli and PH of the Saliva. J Dent (Tehran) 11(6): 672-679.

15. Karygianni L, Manuel Cecere, Alexios LS, Aikaterini A, Elmar H et al. (2014) High-level antimicrobial efficacy of representative Mediterranean natural plant extracts against oral microorganisms. Biomed Res Int 2014: 1-8.

16. Hosokawa Y, Hosokawa I, Shindo S, Ozaki K, Matsuo T (2015) Calcitriol Suppressed Inflammatory Reactions in IL-1 $\beta$-Stimulated Human Periodontal Ligament Cells. Inflammation 38(6): 2252-2258. 
This work is licensed under Creative Commons Attribution 4.0 Licens

DOI: 10.19080/JCMAH.2017.03.555625
Your next submission with Juniper Publishers will reach you the below assets

- Quality Editorial service

- Swift Peer Review

- Reprints availability

- E-prints Service

- Manuscript Podcast for convenient understanding

- Global attainment for your research

- Manuscript accessibility in different formats

( Pdf, E-pub, Full Text, Audio)

- Unceasing customer service

Track the below URL for one-step submission https://juniperpublishers.com/online-submission.php 